\title{
Anxiety and Maternal Fetal Attachment
}

\author{
Evi Wahyuntari ${ }^{1, *}$, Ika Puspitasari ${ }^{2}$ \\ ${ }^{1,2}$ University 'Aisyiyah, West Ringroad 63 of Nogotirto Street Gamping Sleman 55292, Yogyakarta, Indonesia \\ 1evi.wahyuntari@unisayogya.ac.id* \\ *corresponding author \\ Submission date: 20 Juli 2020, Receipt date: 1 September 2020, Publication date: 1 November 2020
}

\begin{abstract}
Maternal Fetal Attachment and fetal growth are strongly influenced by the emotional state or anxiety of the mother, this can be seen from the psychological condition of the mother before giving birth. The psychological condition of the mother will have an impact on the health and development of the fetus. In Indonesia, there are about $28.7 \%$ of pregnant women who experience anxiety in the third trimester. The research objective was to determine the relationship between anxiety and maternal fetal attachment. Cross sectional study. With a population of pregnant women in the third trimester aged 20-35 years as many as 42 respondents. The sampling technique used non probability sampling with a total sampling of 42 pregnant women in the third trimester. The anxiety measurement tool uses the Zung self-rating anxiety scale (ZSAS) questionnaire and the MFA uses the Prenatal attachment inventory (PAI) questionnaire. Pearson analysis (product moment). The $p$ value is 0.023 with a correlation coefficient of -0.350. The conclusion is that there is a relationship between anxiety and maternal fetal attachment at Gamping II Public Health Center with weak relationship closeness, it means that the lower the anxiety score received, the higher the maternal fetal attachment score. Suggestions for pregnant women in the third trimester to be more active in seeking information, both electronic print media, health workers and others about maternal-fetal attachment since pregnancy.
\end{abstract}

Keywords: Anxiety, Maternal Fetal Attachment, pregnancy

\section{INTRODUCTION}

The process of pregnancy will occur hormonal changes. These hormonal changes will cause the mother to experience several emotional changes that will cause anxiety and even depression (Pieter and Lubis, 2011). Anxiety and depression of pregnant women in developed countries is around 7-20\% and in developing countries around more than 20\% (Biaggi et al., 2016), The prevalence of anxiety during pregnancy in several countries, namely Bangladesh is $18 \%$ (Nasreen et al., 2011), China 20.6\% (Kang et al., 2016) and Pakistan 18\% (Karmaliani et al., 2009). Based on research conducted by Mandagi et al (2013) in Indonesia, there are around $28.7 \%$ of pregnant women who experience anxiety in the third trimester.

regnant women who experience anxiety will have an impact on pregnancy, childbirth such as premature delivery and even miscarriage (Novitasari, Budiningsih, 2013). Pregnant women with high anxiety affect fetal nervous development related to cognitive, emotional and behavior until childhood Sandman et al (2011). In addition, pregnant women who experience anxiety will affect the intrauterine environment and 
fetal development and interfere with the blood supply to the fetus which makes the fetus hyperactive so that the child experiences autism Alder et al (2017), (Andriana, 2011).

Several factors that are predicted to affect MFA are gestational age, social support, antenatal care, anxiety, self-confidence, maternal age, parity, marital status, mother's opinion and education (Yarcheski et al., 2009). In Indonesia, the MFA research conducted by Wahyuntari et al. (2019) research the factors that influence MFA, namely planned pregnancy, while age, education, parity and employment have no relationship with MFA Maternal fetal attachment in pregnancy is influenced by anxiety (Pellerone \& Miccichè, 2014). Based on Fauziyyah's research (2016), there is a significant effect on maternal anxiety during pregnancy with MFA. This is indicated by the higher the IPAI score, the lighter the level of anxiety, while the lower the IPAI score, the heavier the level of anxiety. If the mother already has a good attachment, then during pregnancy the mother will do positive behavior such as collecting information about her pregnancy, always doing pregnancy checks on schedule, participating in pregnancy exercises, yoga, preparing funds, place for delivery, baby clothes, transportation so that the mother will feel ready become a mother.

MFA and fetal growth are strongly influenced by the emotional state or anxiety of the mother, this can be seen from the psychological condition of the mother before giving birth. The psychological condition of the mother will have an impact on the health and development of the fetus (Kwon \& Bang, 2011). Research conducted by Pisoni et al., (2014) stated that pregnant women who have high anxiety or depression have a low quality of attachment to the mother and the fetus. According to the results of research by Abazari et al (2017), showing that there is a direct relationship between anxiety and maternal-fetal attachment so that fetal abnormalities and abortion concerns are followed by increased attachment in addition to an increase in the amount of anxiety. It seems that psychological advice is needed to maintain a balance between anxiety and attachment, especially in pregnancy.

The phenomenon that occurs in society today is that many people do not understand the importance of maternal fetal attachment because they do not get psychological counseling during pregnancy regarding maternal fetal attachment (Fenny, 2016).

From the preliminary study, interviews were conducted with ten pregnant women who had their pregnancy checked at the Gamping II Health Center, the results were that 3 out of 10 pregnant women generally felt emotional and physical changes in themselves during pregnancy, mothers felt irritable, often restless, irritable, easily tired, disturbed. digestion and sometimes experiencing shortness of breath (shortness of breath). The mother feels anxious about her pregnancy and the mother's anxiety increases as the time for delivery approaches. Based on the above background, the researcher is interested in conducting research on the relationship between pregnant women anxiety and maternal fetal attachment

\section{RESEARCH METHODS}

Cross sectional study. The population in the study were 42 pregnant women in the third trimester at Gamping II Public Health Center. The sample in the study was taken by total sampling of 42 trimester III pregnant women.

The data collection tool used the Zung self-rating anxiety scale (ZSAS) questionnaire to assess anxiety consisting of 20 questions. The score range for the assessment results was 20-80, with a grouping that was a score of 20-44: mild anxiety, a 
score of 45-59: moderate anxiety, a score of 60 -74: severe anxiety, score 75-80: panic anxiety and the Prenatal Attachment Inventory (PAI) questionnaire to assess MFA developed by Muller (1983) in Abesi et al (2012) as many as 21 questions. In Indonesia, there is already an Indonesian version of PAI and its validity has been tested with the Cronbach's alpha coefficient on the Indonesian version of PAI (IPAI) of 0.937 (Suryaningsih, 2015). The IPAI score range is between 21-84, with the higher score indicating high maternal attachment (Muller, 1993 in Suryaningsih, 2015). The revolutionary measuring instrument in the form of a Likert scale with the statement always, often, almost sometimes, almost never. Measurement results 1) High: 84-52.5, 2) Low: <52.5-21.

Data collection methods were TM III pregnant women who checked their pregnancies at Gamping II Health Center were given an explanation of the research objectives and signed the concent informed sheet. Respondents who were willing then filled out the ZSAS and MFA questionnaires. The data were analyzed descriptively by calculating the frequency distribution. Data analysis using person.

\section{RESULTS AND DISCUSSION}

Based on the results of the study, a description of the characteristics of respondents was obtained in the following table:

Table 1. Characteristics of respondents

\begin{tabular}{|c|c|c|}
\hline Characteristics & Frequency & $(\%)$ \\
\hline \multicolumn{3}{|l|}{ Education } \\
\hline High & 33 & 78,6 \\
\hline Low & 9 & 21,4 \\
\hline \multicolumn{3}{|l|}{ Peofession } \\
\hline Working & 10 & 23,8 \\
\hline Does not Work & 32 & 76,2 \\
\hline \multicolumn{3}{|l|}{ Parity } \\
\hline Primi & 12 & 28,6 \\
\hline Multi & 30 & 71,4 \\
\hline \multicolumn{3}{|l|}{ History of abortion } \\
\hline None & 36 & 85,7 \\
\hline Yes & 6 & 14,3 \\
\hline \multicolumn{3}{|l|}{ Pregnancy planed } \\
\hline Yes & 33 & 78,6 \\
\hline No & 9 & 21,4 \\
\hline
\end{tabular}

Based on table 4.1, respondents are mostly highly educated, namely as many as 33 respondents or (78.6\%). Most of the respondents were not working, as many as 32 respondents or $(76.2 \%)$. Parity of multiparous respondents was 30 respondents or $(71.4 \%)$. Respondents with no history of abortion were 36 respondents or $(85.7 \%)$. For planned pregnancy, most of the respondents planned their pregnancy, namely 33 respondents or $(78.6 \%)$.

Table 2. Pearson correlation with Anxiety Maternal-fetal attachment at Puskesmas Gamping II

\begin{tabular}{llll}
\hline \multirow{2}{*}{ Variable } & \multicolumn{3}{c}{ MFA } \\
\cline { 2 - 3 } & p value & $\mathbf{R}$ \\
\hline
\end{tabular}




\begin{tabular}{lcc}
\hline Anxiety & 0.023 & -0.35 \\
\hline
\end{tabular}

Maternal - fetal attachment is the relationship between mother and fetus during pregnancy. This can be seen as the mother's involvement in showing love, care and commitment to maintaining the health of her fetus. According to Condon and Corkindale (1997, in Ohman, 2011) there are five components of maternal and fetal attachment during pregnancy, namely wanting information about fetal health, pleasure to interact with the fetus, wanting to care for the fetus and serving its needs during pregnancy. If attachment is bad at first then it can have serious consequences for the child. Bowlby explained several things that can happen to children, namely stunted growth, aggressiveness, anxiety, dependence, intellectual retardation, inability to adapt to social environments, psychopaths who are not loving (not showing feelings to others), depression and delinquency.

Maternal fetal attachment plays an important role in the health of the mother and the fetus and has an important influence on the mother's decision to have a healthy lifestyle during pregnancy. Pregnant women who have more affection for their fetus during pregnancy show a more confident attitude in being a mother later and the level of anxiety depression decreases during postpartum (Simpson, J \& Rholes, W, 2010).

The results of statistical tests using the Pearson product moment obtained the results from data processing, namely $\mathrm{P}$ value $0.023<0.05$, which means that there is a relationship between anxiety and maternal-fetal attachments at Gamping II Health Center. The Pearson correlation value -0.350 indicates a negative correlation with weak correlation strength. Which means that the lower the anxiety score received, the higher the maternal fetal attachment score.

This study is in line with Pellerone \& Micciche (2014) that maternal fetal attachment in pregnancy is influenced by anxiety. There is a significant effect on maternal anxiety during pregnancy with MFA. This is indicated by the higher the IPAI score, the lighter the level of anxiety, while the lower the IPAI score, the heavier the level of anxiety. If the mother already has a good attachment, then during pregnancy the mother will do positive behavior such as collecting information about her pregnancy, always doing pregnancy checks on schedule, participating in pregnancy exercises, yoga, preparing funds, place for delivery, baby clothes, transportation so that the mother will feel ready become a mother (Fauziyyah, 2016).

Several factors that are predicted to affect MFA are gestational age, social support, antenatal care, anxiety, self-confidence, maternal age, parity, marital status, mother's opinion and education (Yarcheski et al., 2009). Wahyuntari et al. (2019) research the factors that influence MFA, namely planned pregnancy, while age, education, parity and employment have no relationship with MFA..

In this study, multiparous parity had more high MFA scores because multiparous mothers learned a lot from their attitudes and actions in previous pregnancies. The results of this study are in line with Sukriani (2018) that multigravida mothers always have high MFA scores. This can be due to other factors that are associated with high MFA scores in multigravida mothers such as socio-culture and social support.

In contrast to the research of Hassan et al (2017) where primigravida mothers tend to have high MFA, because psychologically mothers want to have a new role that has never been felt before so that they will be more busy with thoughts and emotions about 
pregnancy and the growing fetus which will cause a high MFA score. . Multipara has no relationship or influence on the score of maternal fetal attachment (Hayat, 2012).

Anxiety is a factor that affects the low attachment between mother and fetus (Pisoni et al, 2014). This can be seen from the results of his research which found that women who were characterized as having low quality fetal attachment were characterized by much higher levels of anxiety and depression.

Suryaningsih (2015) states that when a fetus does not have someone who loves it, then one day it will grow into an emotional child. Therefore the theory of bondage implies that fetuses have the ability to transmit feelings when they experience pressure or pain and parents will also have the sensitivity to be able to communicate with the fetus. So it is very necessary to foster an inner bond between mother and baby or what is known as maternal fetal attachment (Wahyuntari, 2018).

According to Tsao et al., (2016) anxiety can affect the relationship between mother and fetus attachment. Anxiety during pregnancy is the strongest factor affecting the attachment of the mother to the fetus, where women during pregnancy experience significant psychological stress and physical changes such as adjustment of the hormonal system.

In contrast to the research of Gobel et al (2018) that anxiety that occurs during pregnancy does not affect the emotional closeness felt by the child, which means that there is no relationship between the level of anxiety felt by pregnant women, both mild to moderate anxiety and the mother's attachment to the child.

Mental disorders such as anxiety during pregnancy can be bad for both mother and baby in the short or long term. The impact on mothers triggers uterine contractions so that premature delivery, miscarriage and depression (Novitasari, 2013). The result of this condition can increase blood pressure so that it can trigger preeclampsia and miscarriage (Novriani, 2017). Meanwhile, according to Sandman (2011), the bad impact on fetuses with mothers who experience anxiety will affect the results of fetal neurodevelopment related to cognitive, emotional and behavioral development until childhood. The birth of low birth weight babies (LBW) and premature babies is also a negative impact of anxiety in pregnant women (Spitz, 2013).

Significant associations have been found between psychological health and physical health during pregnancy. Researchers suggest that emotional status during pregnancy can directly affect neonatal outcomes such as low birth weight, abortion and resulting in mothers not accepting their pregnancy. Therefore, it is very necessary to develop a bond between mother and baby known as maternal fetal attachment (Wahyuntari et al, 2018).

Other researchers also suggest that special attention should be paid to pregnant women who experience anxiety and depression, because in this condition the mother will inhibit the attachment of the mother-fetus. This is evidenced by the results of his research, which found that women who were characterized as having low-quality fetal attachment reported much higher levels of anxiety and depression. Prenatal attachment can be described as parental emotions, perceptions, and behaviors related to the fetus. This relationship has been described as the most basic form of human intimacy and represents the previously internalized representation of the fetus that both parents acquire and elaborate on during pregnancy.

The quality of the relationship between babies and their parents is an important factor that affects children's development in the future, both cognitively and emotionally. Although it is not clear that demographic, perinatal, and psychological 
variables can be associated with attachment. In this perspective, it is important to recognize the factors that influence parental attachment to the fetus and to prepare for the psychosocial pre-pregnancy period in obstetric clinics, to maintain positive physical and emotional development of the baby and to provide family-centered prenatal care and to provide family-centered prenatal care Pisoniet al (2014).

\section{CONCLUSION}

There is a relationship between anxiety and maternal fetal attachment. The value of the relationship closeness is -0.350 , that the lower the anxiety score received, the higher the anxiety score. Recommendations need to increase counseling for pregnant women in order to optimize MFA so as to improve pregnancy outcomes

\section{REFERENCES}

Abasi, E., Tahmasebi, H., Zafari, M., \&Takami, GN. (2012). Assesment on effective Factots of maternal-Fetal Attachment in pregnant Woman. Life Science Journal Volume 9 No 3, 68-75.

Alder, J., Fink, N., Bitzer, J., Hösli, I., \& Holzgreve, W. (2017). Depression and an xiety during pregnancy: A risk factor for obstetric, fetal and neonatal outcome? A critical review of the literature. Journal of Maternal-Fetal and Neonatal Medicine, 20(3), 189-209.

Andriana, E. (2011). Melahirkan Tanpa Rasa Sakit dengan Metode Relaksasi HypnoBrithing.Jakarta: PT Bhuana Ilmu Populer.

Biaggi, A., Conroy, S., Pawlby, S., \& Pariante, C. M. (2016). Identifying the women at risk of antenatal anxiety and depression: A systematic review. Journal of Affective Disorders, 191, 62-77.

Fauziyyah, A.I. (2016). Hubungan antara Tingkat Kecemasan Ibu dalam menghadapi Persalinan Terhadap Skor Indonesian Version of Prenatal Attachment Inventory (IPAI) pada Ibu Hamil Trimester III di Puskesmas Tegalrejo Yogyakarta.Skripsi: Universitas Aisyiyah Yogyakarta.

Karmaliani, R., Asad, N., Bann, C. M., Moss, N., McClure, E. M., Pasha, O., ... Goldenberg, R. L. (2009). Prevalence of anxiety, depression and associated factors among pregnant women of Hyderabad, Pakistan. International Journal of Social Psychiatry, 55(5), 414-424.

Kang, Y. T., Yao, Y., Dou, J., Guo, X.,\& Li, S. Y. (2016). Prevalence and risk factors of maternal anxiety in late pregnancy in China. International Journal of Environmental Research and Public Health, 13(5).

Kwon, M. K., \& Bang, K. S. (2011). Relationship of prenatal stress and depression to maternal-fetal attachment and fetal growth. Journal of Korean Academy of Nursing, 41(2), 276-283.

Mandagi, D. V. V., Pali, C., \& Sinolungan, J. S. V. (2013). Perbedaan Tingkat Kecemasan Pada Primigravida Dan Multigravida Di Rsia Kasih Ibu Manado. Jurnal E-Biomedik, 1(1), 197-201.

Nasreen, H. E., Kabir, Z. N., Forsell, Y., \& Edhborg, M. (2011). Prevalence and associated factors of depressive and anxiety symptoms during pregnancy: A population based study in rural Bangladesh. BMC Women's Health, 11 .

Novitasari, T., Budiningsih, T. E., \& Mabruri, M. I. (2013). Keefektivan Konseling Kelompok Pra-Persalinan Untuk Menurunkan Tingkat Kecemasan Primigravida Menghadapi Persalinan. Developmental and Clinical Psychology, 2(2), 62-70. 
Novriani, W. S.,\& Febria, S. (2017). Dukungan Keluarga dengan Kecemasan Menjelang Persalinan Trimester III. Jurnal Ipteks Terapan, Vol. 11, No. 1

Pieter, Z. H., \&Namora, L. L. (2011). Pengantar Psikologi Untuk Kebidanan. Jakarta: Kencana.

Pisoni, C., Garofoli, F., Tzialla, C., Orcesi, S., Spinillo, A., Politi, P., ... Stronati, M. (2014). Risk and protective factors in maternal-fetal attachment development. Early Human Development, 90, S45-S46.

Pellerone, M., \& Miccichè, S. (2014). Prenatal Attachment and Anxiety: Women Who Decide to Try in Vitro Fertilization and Women Who Procreate Naturally. Psychology Research, 4(6), 419-427.

Sandman, C. A., Davis, E. P., Buss, C., \& Glynn, L. M. (2011). Prenatal programming of human neurological function. International Journal of Peptides.

Simpson, J. A., \& Rholes, W.S. (2010). Attachment and Relationships: Milestones and Future Directions. Journal of Social and Personal Relationships, 27, 173-180.

Spitz.,\& Elisabeth. (2013). Anxiety Symptoms and Coping Strategies in the Perinatal Period. BMC Pregnancy \& Childbirth, Vol. 13, No. 233

Sukriani, W. (2018). Faktor Risiko Berhubungan dengan Skor Maternal-Fetal Attachment pada Ibu Hamil. Jurnal Kesehatan, 9(2), 185-191.

Suryaningsih, E.K. (2015). Indonesian Version of Prenatal Attachment Inventory(PAI) : A Preliminary Study.Skripsi: National Taipei University of Nursing and Health Sciences.

Wahyuntari, E., Listyaningrum, T.H., \& Istiyati, S. (2018). Buku Ajar Kehamilan dan Maternal Fetal Attachment. Yogyakarta: Unisa Yogya.

Wahyuntari, E., Listyaningrum, T.H., \& Istiyati, S.(2019). Faktor yang berpenmgaruh Terhadap maternal fetal attachment. Media Ilmu Kesehtan, 8 (2), 141-146

Yarcheski, A., Mahon, N. E., Yarcheski, T. J., Hanks, M. M., \& Cannella, B. L. (2009). A meta-analytic study of predictors of maternal-fetal attachment. International Journal of Nursing Studies, 46(5), 708-715. 